\title{
Constitutional Change and Territorial Consent: the Miller case and the Sewel Convention
}

\author{
AILEEN MCHARG
}

\section{BREXIT AND THE TERRITORIAL CONSTITUTION}

The United Kingdom that voted in 1975 on whether to remain in what was then the European Economic Community was a unitary state with a single legislature and single source of sovereign authority. Direct rule had recently been restored in Northern Ireland, and its devolved Parliament abolished; ${ }^{1}$ devolution to Scotland and Wales was under discussion, but no firm proposals were yet being considered. The referendum vote was counted on a territorial basis, and there was concern about the political implications of a territorially-divided result, particularly in the context of rising Scottish nationalism. But it would have been difficult to argue that territorial difference - which in the event never materialised — was constitutionally relevant.

By the time of the 2016 referendum on European Union membership, by contrast, the territorial dimension of withdrawing from the EU was significantly complicated by the existence of devolved legislatures in Scotland, Wales and Northern Ireland. For one thing, devolution raised practical implications for the process of withdrawal given the way in which EU decision-making competences cut across the division between UK and devolved competences, and obligations to comply with EU law and shared responsibility for its implementation were written into the devolution statutes. Brexit would necessarily, therefore, require amendment of the devolution legislation and co-operation between the UK and devolved governments in adjusting laws and policies currently governed by EU law.

More importantly, territorial divisions on EU membership were much more pronounced in 2016. Whereas England and Wales both voted, narrowly, to Leave the EU, ${ }^{2}$ Scotland and Northern Ireland voted more emphatically to Remain, ${ }^{3}$ although England's much larger population (boosted by higher turnouts in England and Wales) ${ }^{4}$ ensured a slim UK-wide majority for Leave. ${ }^{5}$ It is, moreover, clear that these territorial divergences were themselves exacerbated by devolution. This is true, first, in the sense that the existence of devolved institutions provided a platform for the articulation and amplification of political difference; the preoccupations of the devolved political systems were different from those of the UK political system, and in no case (even in Wales) was Euro-scepticism a significant feature of debate. Euro-scepticism - and the associated rise of the UK Independence Party - was therefore a predominantly English phenomenon. But, secondly, devolution - and the perceived advantages that this gave to the devolved nations - was also one of the

\footnotetext{
${ }^{1}$ Northern Ireland Constitution Act 1973.

${ }^{2}$ By $53.4 \%$ and $52.5 \%$, respectively.

${ }^{3}$ By $62 \%$ and $55.8 \%$, respectively.

${ }^{4}$ Turnout was $73 \%$ in England and $71.7 \%$ in Wales, but $67.2 \%$ in Scotland and just $62.7 \%$ in Northern Ireland.

$51.9 \%$.
} 
constitutional discontents fuelling the rise in English nationalism with which the desire for Brexit was clearly associated. ${ }^{6}$

Further, by 2016, territorial difference on the question of EU membership clearly had taken on a constitutional significance. In Northern Ireland, this was due to the role of EU membership in facilitating the cross-border co-operation within the island of Ireland on which the 1998 Good Friday Agreement was based. In Scotland, where the best way to ensure Scotland's continued membership of the EU had been a key issue in the 2014 independence referendum, the Scottish National Party (SNP) had clearly stated in its 2016 Holyrood election manifesto that it would regard Scotland being taken out of the EU against the will of Scottish voters as amounting to 'a significant and material change in the circumstances that prevailed in 2014', sufficient to justify a second independence referendum. ${ }^{7}$ And even in Wales, the Welsh Government regards Brexit as unbalancing the devolution settlement in such a way as to strengthen the case for fundamental reform of the territorial constitution. ${ }^{8}$

In anticipation of a territorially-divided result, the SNP (with the support of Plaid Cymru) made the case during debates on the European Union Referendum Bill for the adoption of a principle of parallel consent: in other words, for Leave to win the referendum, it would need to secure a majority of votes across the UK and in each of the constituent parts of the UK. The analogy was drawn with federal countries like the United States of America, in which constitutional amendment would require consent at both state and federal level. ${ }^{9}$ However, this argument was rejected by both Conservative and Labour MPs on the basis that relations with the EU were reserved to the UK level and therefore the decision to withdraw was one for the UK as a whole. Indeed, one Labour MP rejected the federal analogy, arguing that, since Brexit was a matter of international relations rather than constitutional amendment, there would be no veto for states in the USA. ${ }^{10}$

However, the 'reconstitutionalisation' of the withdrawal decision in $R$ (Miller) $v$ Secretary of State for Exiting the European Union ${ }^{11}$ — i.e., the rejection of the characterisation of the decision to notify the UK's intention to withdraw from the UK under Article 50 TEU as being purely a matter of foreign affairs which could validly be made under the prerogative created an opportunity to revive the argument for devolved consent, this time via the Sewel Convention. If, so the argument went, withdrawal from the EU was a decision requiring statutory authorisation because of its necessary implications for legislation giving effect to EU membership, then it followed that it also had implications for the devolution statutes, which similarly operated on the assumption of continuing EU membership. That being so, legislation authorising withdrawal would require the consent of the devolved legislatures because it would be legislation regarding devolved matters within the meaning of the Sewel convention.

The argument was first raised in the Northern Irish High Court ('HCNI') in the McCord case, in which the court held that legislation was not required to trigger Article 50, but that

\footnotetext{
${ }^{6}$ See generally A Henderson $e t$ al, 'How Brexit was Made in England' (2017) 19 British Journal of Politics and International Relations 631.

${ }^{7}$ Scottish National Party, The Next Steps to a Better Scotland (2016) at 23.

${ }^{8}$ See, eg, Carwyn Jones, Our Future Union - a Perspective from Wales, speech to the Institute for Government, 15 October 2014; Welsh Government and Plaid Cymru, Securing Wales' Future: Transition from the European Union to a New Relationship with Europe (2017).

${ }^{9}$ See Alex Salmond MP and Tasmina Ahmed-Sheik MP, HC Deb Vol 596, at cols 189, 190, and 231 (16 June 2015).

${ }^{10}$ Kevin Brennan MP, ibid, at col 190. See also Chris Philp MP, ibid, at col 189; Dominic Grieve MP, ibid, at col 189; Pat McFadden MP, ibid, at col 206; David Lidington MP, ibid, at col 231.

${ }^{11}$ [2017] UKSC 5, [2017] 2 WLR 583.
} 
even if it had been, it would not attract the operation of the Sewel convention, at least in the Northern Irish context. ${ }^{12}$ Devolution points were also raised in argument in the Divisional Court proceedings in Miller, but the court did not find it necessary to address them. ${ }^{13}$ When the case reached the Supreme Court, however, the devolution dimension took on far greater importance - both because of the joining of the Northern Irish appeals and devolution references with the Miller proceedings, and because of the decision by the Scottish and Welsh governments to intervene in the case. At least as far as the Scottish Government was concerned, this was a decision taken reluctantly, and as much for defensive reasons - to challenge the very narrow reading of the Sewel Convention adopted by the HCNI - as for offensive ones - to gain leverage with which to persuade the UK Government to accept the devolved governments' views regarding the form and domestic implications of Brexit. ${ }^{14}$

Ultimately, the argument for devolved consent was unsuccessful. The Supreme Court unanimously refused to decide the issue, holding that as a matter of convention rather than law, the Sewel convention did not give rise to legally enforceable obligations, nor could the courts give rulings on its operation or scope. Moreover, according to the Court, the statutory 'recognition' of the convention by section 2 of the Scotland Act 2016 (inserting a new section 28(8) into the Scotland Act 1998) had not rendered it any more justiciable. In disposing of the issue in this way, the Court articulated a very narrow conception of its constitutional role, and a very traditional understanding of the territorial constitution, in which the pluralist and decentralised accounts of the location of constitutional authority articulated by or on behalf of the devolved institutions ${ }^{15}$ operate only as political understandings in the shadow of the Westminster Parliament's legal omnipotence.

The effect was to hand a de facto victory to the UK Government, which simply maintained the position it had argued before the Supreme Court that the resulting European Union (Notification of Withdrawal) Act 2017 did not require devolved consent. Notification of withdrawal under Article 50 was duly given without securing the agreement of the devolved governments as to the UK's negotiating position, nor making any concessions to them regarding the domestic implications of Brexit. Nevertheless, the issue of devolved consent to the process of withdrawing from the EU has only been postponed rather than resolved by Miller. The UK Government has conceded that the European Union (Withdrawal) Bill 201719, before Parliament at the time of writing, does in certain respects engage the Sewel convention, ${ }^{16}$ and the devolved governments in Edinburgh and Cardiff are so far insisting that they will not recommend consent unless substantial changes are made. ${ }^{17}$

In the remainder of this chapter, I explore in more detail - and primarily from a Scottish perspective - the territorial dimension to the Miller decision. I discuss, first, the plausibility of the argument that the Sewel convention required devolved consent to the EU (Notification of Withdrawal) Act. Second, I examine the Supreme Court's reasoning about the

\footnotetext{
12 McCord and Agnew [2016] NIQB 85.

13 [2016] EWHC 2768 (Admin), [2017] 1 All ER 158, at [102].

${ }^{14}$ See Scottish Government, Scotland's Place in Europe (December 2016); Welsh Government, Securing Wales' Future, (n 8).

${ }^{15}$ See the written submissions of the Lord Advocate, Counsel General for Wales, and the Agnew claimants, available at: https://www.supremecourt.uk/news/article-50-brexit-appeal.html.

${ }^{16}$ See Explanatory Notes to the European Union (Withdrawal) Bill, at $29-20$ and Annex A.

${ }^{17}$ Scottish Government, Legislative Consent Memorandum: European Union (Withdrawal) Bill, LCM-S5-10, Session 5 (2017) (http://www.parliament.scot/S5ChamberOffice/SPLCM-S05-10-2017.pdf); Welsh Government, Legislative Consent Memorandum: European Union (Withdrawal) Bill (2017) (http://www.assembly.wales/laid\%20documents/lcm-ld11177/lcm-ld11177-e.pdf).
} 
justiciability of conventions and of section 28(8) of the Scotland Act 1998. Finally, I consider the implications of Miller for the future of the territorial constitution and of the Sewel Convention as a technique for managing territorial relations.

\section{THE SEWEL CONVENTION AND CONSTITUTIONAL CHANGE}

\section{A. The Evolution of the Sewel Convention}

The Sewel convention, as it has developed since 1999, has become a central mechanism for the management of territorial relations within the UK; in particular for regulating the interface between reserved and devolved legislative competences. It performs two important functions. The first is a defensive one. It provides the devolved legislatures with a reassurance, in the face of the continuing assertion of Westminster's legislative omnipotence, that their primary political authority in relation to devolved matters will be respected through the requirement that Westminster will normally gain the consent of the relevant devolved legislature before legislating with regard to devolved matters. Secondly - and arguably more importantly in practice, at least in the early years of devolution ${ }^{18}$ - it performs a facilitative function. In other words, it enables co-operation between the UK and devolved governments over the achievement of their policy goals, either where a UK-wide approach is considered desirable notwithstanding devolution, or where competence constraints might inhibit the effective realisation of devolved policy aims. The convention thus addresses two key weaknesses in the UK's formal arrangements for territorial governance: the lack of legal entrenchment of the powers of the devolved legislatures; and the weakness of mechanisms for shared rule. In so doing, it shifts the UK's territorial constitution in practice from a system of devolution within a unitary state towards a more federal model, thus underlining its constitutional significance.

Sewel is a somewhat unusual convention in that it originated in an explicit statement of intent by the Scottish Office minister, Lord Sewel, during parliamentary debate on the Scotland Bill 1998. Discussing the use of what was to become section 28(7) of the Scotland Act 1998, which states that the power of the UK Parliament to make laws for Scotland is unaffected by the establishment of the Scottish Parliament, Lord Sewel went on to say:

[h]owever, as happened in Northern Ireland earlier in the century, we would expect a convention to be established that Westminster would not normally legislate with regard to devolved matters in Scotland without the consent of the Scottish Parliament. ${ }^{19}$

This expectation was subsequently reflected in, and amplified by, the Memorandum of Understanding agreed between the UK and devolved governments and various Devolution Guidance Notes (DGNs), first published in December 1999. DGN 10 (on Post-Devolution Primary Legislation Affecting Scotland) ${ }^{20}$ provides that the consent of the Scottish Parliament is normally required for legislation which 'contains provisions applying to Scotland and which are for devolved purposes' or 'which alter the legislative competence of the Parliament or the

\footnotetext{
${ }^{18}$ See A Page and A Batey, 'Scotland's Other Parliament: Westminster Legislation about Devolved Matters in Scotland Since Devolution' [2002] PL 501.

${ }^{19}$ HL Deb, Vol 592, col 791 (21 July 1998).

${ }^{20}$ Available at: https://www.gov.uk/government/publications/devolution-guidance-notes.
} 
executive competence of the Scottish Ministers'. Trench refers to these two categories as the policy arm and constitutional arm of the convention, respectively. ${ }^{21}$ According to DGN 10, consent is not, however, required for legislation affecting Scotland which is for reserved purposes but which makes 'incidental or consequential changes to Scots law on non-reserved matters' even though it recognises that such effects might in some cases be significant. ${ }^{22}$ Nevertheless, the distinction between legislation for reserved and devolved purposes is not watertight. Varying the scope of devolved legislative or executive competence is itself a reserved matter, yet attracts the requirement of consent. Giving evidence to the Scottish Parliament's Procedures Committee in 2005, Lord Sewel argued that the inclusion of such legislation within the scope of the Convention went beyond its original purpose and 'results in real confusion. ${ }^{23}$

McCorkindale notes that the practice of seeking devolved consent in Scotland has also evolved in other ways since $1999,{ }^{24}$ including the development of a much more formal procedure for seeking consent and scrutinising legislative consent memorandums, ${ }^{25}$ and the granting of conditional consent. ${ }^{26}$ There is also a range of obligations on the UK Government, for instance, concerning when and how consent will be sought to government Bills, and an expectation that it will oppose Private Members Bills where devolved consent has not been granted. ${ }^{27}$

The evolving nature of legislative consent has created some uncertainty as to which elements are properly regarded as part of the convention (and therefore constitutionally binding), and which are mere practice. In giving effect to the Smith Commission's recommendation that the convention should be put on a statutory footing, ${ }^{28}$ the UK Government chose to employ the precise words used by Lord Sewel in 1998. Resisting attempts to amend the provision to make it clear that the statutory provision covered both the policy arm and the constitutional arm of the Sewel convention, the Advocate General for Scotland, Lord Keen of Elie QC, sought to distinguish the convention per se, which he claimed was limited to Lord Sewel's original statement, from the broader practice that had grown up around legislative consent as detailed in DGN $10^{29}$ — a claim he repeated during oral argument before the Supreme Court in Miller.$^{30}$ Indeed, the importance of resisting this attempt to narrow the scope of the Convention was one reason why the Scottish Government felt it necessary to intervene in the Supreme Court proceedings.

Seeking to distinguish the convention from the practice of the convention was, however, misconceived. As I have argued elsewhere, the obligatory quality of a convention cannot be established by mere declaration, but rather is constituted through the practice of

\footnotetext{
${ }^{21}$ A Trench, 'Brexit, Article 50 and Devolved Legislative Consent', Devolution Matters Blog, 25 November 2016.

${ }^{22}$ Department for Constitutional Affairs, DGN10 (2005), at paras 4 and 7.

${ }^{23}$ Submission by Lord Sewel, Scottish Parliament Procedures Committee, The Sewel Convention, $7^{\text {th }}$ Report 2005 , SP Paper 428 (Session 2), at Annex C, paras 9 - 10.

${ }^{24}$ C McCorkindale, 'Echo Chamber: The 2015 General Election at Holyrood - A Word on Sewel', Scottish Constitutional Futures Forum Blog, 13 May 2015.

${ }^{25}$ See Standing Orders of the Scottish Parliament $\left(5^{\text {th }}\right.$ edn, $5^{\text {th }}$ revision, May 2017) at ch 9B.

${ }^{26}$ eg to what became the Scotland Act 2012, S3M-8813, SP OR, 10 March 2011.

${ }^{27}$ DGN 10, (n 20).

${ }^{28}$ Report of the Smith Commission for Further Devolution of Powers to the Scottish Parliament (2014).

${ }^{29}$ HL Deb, Vol 769, cols 305 - 6 (24 February 2016).

${ }^{30}$ Transcript, day 4 (8 December 2016) at 135-136, available at: https://www.supremecourt.uk/news/article-50brexit-appeal.html.
} 
constitutional actors. ${ }^{31}$ While Lord Sewel's statement may be understood as an attempt to create a constitutional rule regarding the seeking of devolved consent, it is not determinative of the scope of that rule. Rather it depends, as in Jennings' celebrated formulation, upon a combination of constitutional practice, the attitudes of the relevant constitutional actors towards that practice, and the existence of sound constitutional reasons for regarding the practice as obligatory. ${ }^{32}$ Thus, in the McCord case, it was the absence of 'consistent practice and usage', under either the Government of Ireland Act 1920 or under the Northern Ireland Act 1998, which led Maguire $\mathrm{J}$ to reject the broader understanding of the convention as encompassing the constitutional arm as well as the policy arm. ${ }^{33}$ In relation to Scotland, however, the Lord Advocate presented copious evidence of legislative consent motions being sought and granted in relation both to Bills legislating for devolved purposes and Bills altering legislative or executive competence. ${ }^{34}$ In both cases, moreover, there is evidence that a refusal or grant of only qualified consent has been respected. ${ }^{35}$

Nevertheless, some uncertainty continues to surround the scope of the Sewel convention as it applies to the Scottish Parliament. One issue concerns how far the convention extends to legislation on reserved matters which also has implications for devolved matters. A number of controversies have arisen in recent years concerning Bills which would clearly be outwith Holyrood's legislative competence, but nonetheless have effects on devolved matters which might be regarded as more than merely incidental. ${ }^{36}$ Conversely, debate has also arisen over whether some Bills affecting the scope of devolved competence (such as a Bill repealing or reforming the Human Rights Act 1998) might have too minimal an effect to engage the requirement of legislative consent. ${ }^{37}$ The second area of uncertainty relates to the existence of exceptions to the Convention. The wording consistently adopted both by Lord Sewel and in subsequent formulations is that consent is normally required for legislation with regards to devolved matters, a proviso that must be understood in normative rather than purely descriptive terms. Since the only significant examples of the UK Parliament legislating with regard to devolved matters without devolved consent ${ }^{38}$ relate to the wholly exceptional circumstances of Northern Ireland - in situations in which devolved government has actually or effectively broken down - it is unclear for what reasons it might be legitimate either to dispense with the requirement to seek consent or to ignore a refusal of consent. Both of these areas of uncertainty

\footnotetext{
${ }^{31}$ A McHarg, 'Reforming the United Kingdom Constitution: Law, Convention, Soft Law' (2008) 71 MLR 853, at $857-861$.

${ }^{32}$ I Jennings, The Law and the Constitution ( $5^{\text {th }}$ edn, 1959), at 136.

${ }^{33}$ McCord and Agnew (n12), at [119].

${ }^{34}$ See Written Case of the Lord Advocate, (n 15) at Annex 1. The practice in Wales is more complex, but also supports the wider understanding of the convention - see A Trench, 'Legislative Consent in Wales' Devolution Matters Blog, 28 October 2015.

${ }^{35}$ eg in relation to the Welfare Reform Act 2012 and the Scotland Act 2012.

36 eg in relation to the Trade Union Act 2016, see A Trench, 'Legislative Consent for the Trade Union Bill' Devolution Matters Blog, 17 October 2015; in relation to the Immigration Act 2016, see T Mullen and S Craig, 'The Immigration Bill, Reserved Matters and the Sewel Convention', Scottish Constitutional Futures Forum Blog, 15 April 2016, I Jamieson, 'Interpretation of the Sewel Convention, the Purpose Test and the Immigration Bill', Scottish Constitutional Futures Forum Blog, 7 May 2017, T Mullen and S Craig, 'The Immigration Act 2016, Reserved Matters and the Sewel Convention: A Reply, Scottish Constitutional Futures Forum Blog, 28 May 2016. 37 See I Jamieson, 'The Repeal of the Human Rights Act and the Sewel Convention in Scotland' Scottish Constitutional Futures Forum Blog, 12 June 2015; M Elliott, 'The Scottish Parliament, the Sewel Convention and Repeal of the Human Rights Act: a Postscript' Public Law for Everyone Blog, 28 September 2015.

38 There has been at least one inadvertent breach of the Convention - see R Edwards, 'Scottish Councils Robbed of Powers to Deal with Litter - By Westminster', Sunday Herald (20 March 2016).
} 
were implicated in the application of the Sewel Convention to legislation authorising withdrawal from the EU.

\section{B. The Sewel Convention and EU Withdrawal}

In assessing whether the EU (Notification of Withdrawal) Act 2017 should have been subject to devolved consent, two issues therefore require to be addressed. First, was it legislation 'with regard to devolved matters'? Secondly, if so, was this nevertheless a situation in which the requirement of devolved consent could justifiably be dispensed with?

The argument in Miller was mainly addressed to the first issue. The Lord Advocate, the Counsel General for Wales and the Agnew claimants in the Northern Ireland reference all agreed with the Miller claimants that legislation was required in order to trigger Article 50. However, they claimed that the impact of EU withdrawal on the devolution statutes - like the European Communities Act 1972, also regarded as constitutional statutes ${ }^{39}$ — provided an independent reason why notification of withdrawal could not be given under the foreign affairs prerogative. That being so, they argued, an Article 50 Bill would engage the Sewel convention both in its policy arm - because it would interfere with legislation in devolved policy areas which relied upon EU law - and, more importantly, in its constitutional arm, by interfering with key provisions in the devolution statutes requiring the devolved governments and legislatures to implement and comply with EU law.

The UK Government's response ${ }^{40}$ was to insist upon its characterisation of the decision to withdraw from the EU as a matter of foreign affairs, and upon the ambulatory nature of the relationship between domestic statutes and EU law. Thus, since international relations, including relations with the EU, are matters reserved to the UK level, and since the devolution statutes assumed, but did not require, continuing EU membership, they did not, it argued, have the effect of ousting the foreign affairs prerogative. Indeed, according to the UK Government, the EU law provisions in the devolution statutes were mere belt and braces provisions included to ensure that the UK remained in compliance with its EU law obligations, but strictly speaking unnecessary - the removal of which would not render the devolution legislation unworkable. Thus, even if legislation was required to trigger Article 50, the Sewel Convention would not be engaged because the reservation of relations with the EU meant that it would not be legislation 'with regard to a devolved matter'.

The UK Government's attempt to downplay the significance of the embedding of EU law into the devolution statutes is unconvincing. In the first place, although relations with the EU may be reserved, observing and implementing EU law is not. It was recognised from the outset of devolution that this made EU law effectively an area of shared power in which the devolved governments were active participants in the formulation of UK policy on EU matters in devolved areas, ${ }^{41}$ and where there was dual UK and devolved responsibility for

\footnotetext{
${ }^{39}$ Thoburn v Sunderland City Council [2001] EWHC Admin 195, [2003] QB 151; H v Lord Advocate [2012] UKSC 24, [2013] 1 AC 413.

${ }^{40}$ See Supplementary Supreme Court Printed Case of the Secretary of State for Exiting the European Union, available at: https://www.supremecourt.uk/news/article-50-brexit-appeal.html.

${ }^{41}$ Indeed, Harrington identifies a more general sharing of the UK government's treaty making powers with subnational authorities - see J Harrington, 'Scrutiny and Approval: the Role for Westminster-Style Parliaments in Treaty-Making' (2006) 55 ICLQ 121, at 148 - 151.
} 
implementation and compliance with EU law. ${ }^{42}$ The inclusion of specific implementation and compliance obligations in the devolution statutes, although from one perspective strictly unnecessary, therefore has had real consequences for the ways in which EU law has been implemented and enforced in the devolved territories. More generally, the removal of the EU tier of governmental decision-making will necessarily have major implications for policymaking in devolved areas, and for the balance of power between the UK and devolved levels. That said, what precisely the implications of Brexit for the devolution settlements - and indeed its implications for the status of EU law in the domestic legal systems more generally - will be is not a straightforward issue, as subsequent debates over the EU (Withdrawal) Bill have demonstrated. Nevertheless, having accepted the Miller claimants' arguments about the inevitable domestic effects of triggering Article 50, thereby collapsing the distinction between action on the international and domestic planes, it was difficult for the Supreme Court majority to resist the logic that the devolution statutes would also be affected:

As already explained, it is normally impermissible for statutory rights to be removed by the exercise of prerogative powers in the international sphere. It would accordingly be incongruous if constraints imposed on the legislative competence of the devolved administrations by specific statutory provisions were to be removed, thereby enlarging that competence, other than by statute. A related incongruity arises by virtue of the fact that observance and implementation of EU obligations are a transferred matter and therefore the responsibility of the devolved administration in Northern Ireland. The removal of a responsibility imposed by Parliament by ministerial use of prerogative powers might also be considered a constitutional anomaly. ${ }^{43}$

But even if the devolution statutes were necessarily affected by the triggering of Article 50, the argument that withdrawal legislation would then engage the Sewel convention faced the further problem that — as the UK Government pointed out and the Supreme Court acknowledged - devolved consent had not previously been sought for other legislation affecting the EU, including the European Communities (Amendment) Act 2002, the European Parliamentary Election Act 2002, the European Union Amendment Act 2008, the European Union Act 2011, and the European Union Referendum Act 2015. ${ }^{44}$

If conventions are founded in practice, is the absence of a direct precedent fatal to the argument that a conventional obligation arises? Not necessarily. In any system of rule-making based on precedent situations are unlikely to recur exactly. A judgment therefore has to be made about whether the current situation is materially the same or materially different to those in which the rule has (or has not) previously been applied. For instance, the Lord Advocate pointed to precedents where consent had been sought for a UK Bill affecting foreign affairs, but which nevertheless touched upon reserved matters. ${ }^{45}$ Conversely, the issues raised by previous EU-related legislation might have been materially different — for instance, it is hard to see how the EU Referendum Act could by itself be said to have affected devolved matters. Alternatively, a previous failure to seek consent might simply have been an oversight, or may

\footnotetext{
${ }^{42}$ See Scottish Office, Scotland's Parliament (Cm 3658, 1997) at ch 5; Concordat on Co-ordination of EU Policy Issues, in the Memorandum of Understanding and Supplementary Agreements Between the United Kingdom Government, the Scottish Ministers, the Welsh Ministers, and the Northern Ireland Executive Committee (2013).

${ }^{43}$ Miller (n 11), at [132].

${ }^{44}$ Supplementary Printed Case, (n 40) at para 36.

${ }^{45}$ See Written Case, (n 15) at para 77, citing the International Organisations Bill.
} 
be an indication that the Convention has since evolved, or that a relevant exception to the convention applied.

To assist in making sense of ambiguous practice, regard must be had the constitutional purpose(s) that the convention may be said to serve or the constitutional values that it protects. Elliott argues that the constitutional value served by Sewel is respect for devolved autonomy. ${ }^{46}$ In its original, policy arm, it serves that value in a fairly direct way_ — by preserving the sphere of devolved competence against Westminster encroachment. As regards the constitutional arm of the convention, Elliott argues it again reflects the value of respect for devolved autonomy, 'but in broader, more diffuse terms':

While it is relatively easy to see why the Convention should require consent before any reduction in devolved authority ... the position is more complex in respect of UK legislation extending devolved authority. At first glance ... it is difficult to see what the constitutional rationale might be for requiring consent to more devolution. However, the argument, presumably, is that the devolved institutions should be masters - or at least participants in the shaping - of their own destiny, and that it would contravene the spirit of devolution and the constitutional value of respect for devolved autonomy to foist upon devolved institutions unwanted powers (or, for that matter, to confer powers in a way or subject to conditions that were unpalatable to the relevant devolved body).

In fact, it is often argued that the requirement of devolved consent to changes in executive or legislative competences derives from the fact that the devolution statutes themselves contain mechanisms for adjusting the allocation of competences by Order in Council, which require the consent of both the UK and devolved legislatures. ${ }^{47}$ The Sewel convention thus prevents this procedure being bypassed through the use of primary rather than secondary legislation. But in a more fundamental sense it may be seen to reflect an important general principle underpinning devolution, which is that powers are devolved to particular territories only with their consent. ${ }^{48}$ In practice, the contemporary history of devolution is not one of a top-down transfer of power from Westminster to the devolved territories, but rather of bottom-up demand for increased autonomy to which Westminster has given effect. Accordingly, the constitutional arm of the Sewel convention secures the sharing of political and legal authority in relation to the determination of the scope of devolved autonomy. Indeed, as noted above, this idea of power sharing — of co-operation in the fulfilment of political aspirations - is as important to an understanding of the operation of the Sewel convention in general as is its role in preserving the boundary between reserved and devolved competences.

As regards the demand for devolved consent in relation to withdrawal from the EU (as also for the demand for consent to a putative human rights reform Bill), then, whether this is regarded as falling within the scope of the principles underpinning the Convention depends on which of these constitutional rationales - autonomy or power-sharing — is emphasised. If the focus is on devolved autonomy, then the devolved governments might be accused of seeking to extend the consent requirement into new constitutional territory. What is novel about these situations is that they involve a demand for devolved consent not in relation to the direct amendment of the devolution legislation, but rather in relation to $U K$-wide legislation which forms part of the broader constitutional context in which the devolution arrangements are

\footnotetext{
46 Elliott (n 37).

47 Scotland Act 1998, s30; Northern Ireland Act 1998, s4(2); Government of Wales Act 2006, s109.

48 See A Tomkins, 'Scotland's Choice, Britain's Future' (2014) 130 LQR 215, at 228.
} 
situated. Alternatively, however, this can be seen as a natural extension of a principle of constitutional power-sharing which the Convention already embodies, understanding the devolution statutes not as discrete sub-national constitutions of purely local significance, but as conditioned by and conditioning the UK constitution as a whole.

But even if the argument can be made in principle that the convention was engaged by Article 50 legislation, the question still needs to be addressed whether this was a situation in which an exception could legitimately have been made. After all, withdrawing from the EU is anything but 'normal'. In their submissions to the Supreme Court, neither the claimants and interveners nor the UK Government addressed what 'normally' means within the terms of the Sewel convention; all parties accepted that it must be determined politically rather than judicially. ${ }^{49}$ Nevertheless, political decisions as to when it is appropriate to depart from convention ought also to be guided by considerations of constitutional propriety.

Extrapolating from experience in relation to Northern Ireland, and from what little discussion there has been of this issue, two classes of cases can be suggested in which devolved consent in relation to UK legislation on devolved matters might legitimately be disregarded. The first are cases of necessity. Thus, for example, the enactment by the UK Parliament in November 2017 of a Budget Act for Northern Ireland ${ }^{50}$ can be regarded as justified by necessity in the circumstances of ongoing failure to form a government in Northern Ireland following the Assembly elections in March 2017. Similarly, it was suggested during debate on the Scotland Bill 1998 that, were the Scottish Parliament to refuse to legislate in conformity with international obligations, the UK Parliament would be justified in legislating for it $^{51}-$ such action being necessary to avoid breaching international law. The second class of cases, identified by Calvert, ${ }^{52}$ and evidenced by the resumption of direct rule in Northern Ireland in 1972 in circumstances of civil unrest provoked by perceived systematic discrimination against the Catholic minority, is where the devolved legislature can be regarded as having abused the power entrusted to it. Again, it was suggested during debates on the Scotland Bill that if the Scottish Parliament proposed to budget outwith its means the UK Parliament would be justified in legislating to remedy the situation. ${ }^{53}$

Can either of these exceptions be said to apply to the EU (Notification of Withdrawal) Act? Clearly, the majority of MPs and peers considered themselves constitutionally bound to give effect to the referendum result and, insofar as a requirement of devolved consent might have prevented that, it might therefore be said to have been necessary to disregard the Sewel Convention. However, this argument is problematic given that the constitutional authority of the referendum itself is disputed - both generally, and specifically in relation to Scotland and Northern Ireland. Certainly, the constitutional recognition of the Sewel convention is stronger than that of any equivalent putative convention that referendum results should be respected. Alternatively, it might be argued that the devolved governments were abusing their power by seeking to do indirectly via the Sewel convention what they had failed to do directly in the EU Referendum Act, namely to secure a principle of parallel consent to Brexit. But, again, this argument is problematic: first, in that, as a general proposition, the Sewel Convention acts to

\footnotetext{
${ }^{49}$ See also Lady Hale, 'The United Kingdom Constitution on the Move', The Canadian Institute for Advanced Legal Studies’ Cambridge Lectures 2017 (7 July 2017) 8, available at: https://www.supremecourt.uk/docs/speech-170707.pdf.

${ }^{50}$ Northern Ireland Budget Act 2017.

${ }^{51}$ Dominic Grieve MP, HC Deb, Vol 305, at col 151 (13 January 1998).

${ }^{52}$ H Calvert, Constitutional Law in Northern Ireland: A Study in Regional Government (1968) at 91 - 92.

${ }^{53}$ Lord Sewel, HL Deb, Vol 592, at col 1704 (30 July 1998).
} 
modify the strict letter of the law; second, because devolution itself operates as a protective mechanism in light of the permanent minority status of the devolved nations in the UK Parliament; and third because an express reason given for rejecting the principle of parallel consent was that the referendum was only advisory. ${ }^{54}$

In both respects, then, the application of the Sewel Convention to the EU (Notification of Withdrawal) Act took us into highly uncertain constitutional territory. Here we see both the advantages and disadvantages of constitutional regulation through conventions. On the one hand, their inherent flexibility allows them to evolve and adapt to new situations and to accommodate new constitutional claims. On the other hand, such evolution depends upon consensus amongst the relevant constitutional actors as to what obligations they impose. Absent such consensus, there is no mechanism - unlike for legal rules - for the authoritative resolution of disputes about the meaning of conventions, and this is most problematic precisely in circumstances such as Brexit where the constitutional stakes are high and the likelihood of achieving consensus is correspondingly low.

\section{THE JUSTICIABILITY OF THE SEWEL CONVENTION}

In the end, this key distinction between legal and conventional rules was determinative of the way in which the Supreme Court handled the issue of devolved consent. Notwithstanding the passage quoted above,${ }^{55}$ the court ultimately considered it unnecessary to reach a definitive view on whether the devolution statutes imposed an independent requirement for legislation to authorise the triggering of Article 50. ${ }^{56}$ This was because the consequences of such a finding - the implications for the application of the Sewel convention - were, in the Court's view, non-justiciable. Citing the decisions of the Supreme Court of Canada in Re Resolution to Amend the Constitution (Patriation Reference) ${ }^{57}$ and of the Privy Council in Madzimbamuto $v$ Lardner-Burke, ${ }^{58}$ the Court considered it inherent in the nature of conventions that they are not legally enforceable. While this does not necessarily render them legally irrelevant, the court nevertheless considered that the role of judges in relation to conventions was a very narrow one:

Judges ... are neither the parents nor the guardians of political conventions; they are merely observers. As such, they can recognise the operation of a political convention in the context of deciding a legal question (as in the Crossman diaries case - Attorney General v Jonathan Cape Ltd [1976] 1 QB 752), but they cannot give legal rulings on its operation or scope, because those matters are determined within the political world. As Professor Colin Munro has stated, "the validity of conventions cannot be the subject of proceedings in a court of law" - (1975) 91 LQR 218, 228..$^{9}$

Nor in the Court's view, did the statutory recognition of the Sewel convention change its juridical status. In inserting section 28(8) into the Scotland Act 1998 (and enacting a similar provision in the Wales Act 2017):

\footnotetext{
${ }^{54}$ David Lidington MP, HC Deb, Vol 597, at col 231 (16 June 2015).

55 (n 43).

${ }^{56}$ Miller (n 11) at [132].

${ }^{57}$ [1981] 1 SCR 753.

58 [1969] 1 AC 645.

${ }^{59}$ Miller (n 11), at [146].
} 
the UK Parliament is not seeking to convert the Sewel Convention into a rule which can be interpreted, let alone enforced, by the courts; rather, it is recognising the convention for what it is, namely a political convention, and is effectively declaring that it is a permanent feature of the relevant devolution settlement. ${ }^{60}$

All three elements of the court's decision - the necessity of resolving the issue of devolved consent; the role of the courts in the interpretation of conventions; and the effect of statutory recognition - were more contestable than its relatively cursory treatment of them acknowledged.

\section{A. Was the Sewel Convention Relevant to the Legal Question Before the Court?}

Conventions may be relevant to the resolution of legal issues in various ways, both direct and indirect. Directly, a legal rule may refer to a convention - for instance, statutory references to the conventional institutions of the Cabinet and the Prime Minister - such that the operation of the legal rule cannot be understood without also understanding the relevant convention. Alternatively, the application of a legal rule may depend upon the existence or scope of a convention. In the Jonathan Cape case, ${ }^{61}$ for example, the existence of a conventional obligation of Cabinet confidentiality established the factual nexus of confidentiality, plus the public interest justification, for holding that the unauthorised publication of ministerial memoirs amounted prima facie to the common law tort of breach of confidence. Similarly, in Evans $v$ Information Commissioner ${ }^{62}$ whether the government was justified, on public interest grounds, in refusing to release Prince Charles' correspondence with ministers under the Freedom of Information Act 2000 depended upon whether or not the government was correct to claim that the correspondence fell within the scope of the education convention.

Indirectly, the background presence of a conventional rule may act as a source of constitutional principle affecting the development or application of legal rules. ${ }^{63}$ For instance, in Carltona Ltd v Commissioner of Works, ${ }^{64}$ the conventional relationship between ministers and civil servants was the justification for holding that the non-delegation doctrine does not apply in circumstances where decisions are made by civil servants on behalf of ministers. More generally, the convention of ministerial responsibility to Parliament provides support for judicial deference to ministers on questions of particular political sensitivity.

In Miller, arguments of both a direct and indirect nature were made for the relevance of the Sewel convention to the resolution of the legal issues before the Supreme Court. The Lord Advocate and the Agnew appellants argued that it was directly relevant to the question of the UK's 'constitutional requirements' for a decision to withdraw from the EU under Article 50. ${ }^{65}$ This was undoubtedly a legal question on which the domestic courts could legitimately rule (Article 50 having been incorporated into domestic law by the European Union (Amendment) Act 2008); and there was no reason why, they argued, 'constitutional requirements' should be

\footnotetext{
60 ibid at [148].

${ }^{61}$ [1976] 1 QB 752.

62 [2012] UKUT 313 (AAC).

${ }^{63}$ See generally, M Elliott, 'Parliamentary Sovereignty and the New Constitutional Order: Legislative Freedom, Political Reality and Convention' (2002) 25 Legal Studies 341.

64 [1943] 2 All ER 560.

${ }^{65}$ Lord Advocate's written case, (n15) at paras 8, 85; Agnew (n15), at [123]-[125].
} 
regarded as being limited to legal rules. More indirectly, the Counsel General for Wales argued that the scope of the prerogative should be interpreted in the light of background constitutional principles, including the Sewel convention, and should therefore not be given a meaning which would allow ministers (in effect) to amend the devolution statutes without devolved consent. ${ }^{66}$ For its part, the UK Government argued that the Convention was not relevant to the issues before the court. The issue was the proper use of the prerogative, not the enactment of legislation; accordingly, any question of the application of the Sewel convention was moot. ${ }^{67}$

The Supreme Court did not address these arguments directly. However, given the generally advisory nature of the decision in Miller - there was no actual use of the prerogative under review by the court either - the UK Government's argument about mootness seems unpersuasive. On the other hand, the Counsel General's argument also seems weak, insofar as the arguments about the impact on the devolution statutes simply reinforced the more general arguments for holding that there was no prerogative power to trigger Article 50, rather than raising distinct legal issues. As Elliott has put it, 'the resolution of the legal question ("Was legislation needed?") bore on the question whether the convention was engaged, but the latter did not bear upon the former.' ${ }^{68}$

As regards the argument that the Sewel convention was one of the 'constitutional requirements' referred to in Article 50, Grant describes this as also being 'clearly flawed' ${ }^{69}$ But it is not obvious that this is the case. Admittedly, the Supreme Court did not present the issue as one of interpretation of Article 50. As described in the majority judgment,

[t]he question before this Court concerns the steps which are required as a matter of UK domestic law before the process of leaving the European Union can be initiated. The particular issue is whether a formal notice of withdrawal can lawfully be given by ministers without prior legislation passed in both Houses of Parliament and assented to by HM The Queen. ${ }^{70}$ (emphasis added)

However, the Court appears to have deliberately chosen to narrow the issues in this way so as to avoid engaging with the wider requirements of withdrawal, such as the constitutional (rather than legal) authority of the referendum (referred to in Shindler as one of the requirements of a decision to withdraw from the EU) ${ }^{71}$ and the role of the devolved legislatures. That the case was actually concerned with the constitutional validity of the decision to leave the EU, rather than purely with the legal validity of a withdrawal notification, is made clear by the absurdity of subsequent arguments that, notwithstanding that Parliament has now authorised the making of a valid withdrawal notification as required by Miller, the constitutional requirements for a decision to leave the EU have still not been met. ${ }^{72}$ This being so, there is no obvious

\footnotetext{
66 ibid, paras $19-21$.

67 (n 40) at para 3.

68 'The Supreme Court's Judgment in Miller: In Search of Constitutional Principle' (2017) 76 CLJ 257, at 277.

69 J Grant, 'Prerogative, Parliament and Creative Constitutional Adjudication: Reflections on Miller' (2017) 28 King's Law Journal 35, at 57.

${ }^{70}$ Miller (n 11), [2].

${ }^{71}$ Shindler $v$ Chancellor of the Duchy of Lancaster [2016] EWCA Civ 469, [2017] QB 226.

72 See, eg, the so-called 'Three Knights Opinion', which argues that Parliamentary approval of the terms of withdrawal is also required (D Edward et al, In the Matter of Article 50 of the Treaty on European Union (10 February 2017 , available

at: https://www.bindmans.com/uploads/files/documents/Final_Article 50_Opinion_10.2.17.pdf) or Sir Louis BlomCooper's bizarre argument that 'The "constitutional requirements" [referred to in Art 50] must surely take account
} 
justification for limiting the meaning of the 'constitutional requirements' referred to in Article 50 to legal rules, especially in view of the Supreme Court's acknowledgment of the fundamentally important role that conventions play in the UK constitution. ${ }^{73}$

\section{B. The Role of the Courts in Relation to Conventions}

If it is plausible to argue that the Sewel convention was relevant to the resolution of the legal issues before the Supreme Court, was it nevertheless correct to say that courts are only permitted to recognise the existence of conventions and not to give rulings on their operation or scope? In fact, the Supreme Court again seems to have adopted an excessively narrow view of the appropriate judicial role in relation to conventions. There are several cases, both in the UK and elsewhere, in which courts have gone further and given rulings on the meaning of disputed conventional rules, hearing evidence and argument to enable them to do so. ${ }^{74}$ Indeed, in the McCord case, the HCNI was prepared to rule on the scope of the Sewel convention, even though it considered that no issue of the application of the convention arose on the facts of the case. As others have pointed out, ${ }^{75}$ the Supreme Court was not bound to follow the precedents of lower UK or foreign courts. Nevertheless, it gave no reasons for adopting a narrower view of the permissible judicial role in relation to conventions, nor even acknowledged that it was doing so.

If courts are permitted to recognise conventions, it is, of course, inevitable that they will have to take a view on the meaning of those conventions. There is, nevertheless, a distinction between this unavoidable process of interpretation, and being willing to settle disputes about the correct interpretation of conventions. There might well be a concern that a declaratory role for judges in relation to the meaning of disputed conventions would be tantamount to enforcement because of the resulting moral pressure to comply with a judicial ruling, ${ }^{76}$ and hence would collapse the distinction between judicially-enforceable laws and politicallyenforceable conventions. This would be particularly problematic in cases where conventions modify the operation of legal rules because, as the Supreme Court of Canada noted in the Patriation Reference, 'the courts are bound to enforce the legal rules'. ${ }^{77}$ There was thus a specific concern in Miller that for the Supreme Court to rule on the meaning of the Sewel convention would lead it to question proceedings in Parliament, contrary to Article 9 of the Bill of Rights. ${ }^{78}$

A number of responses can be made to these concerns. In the first place, it is not clear that judicial enforcement, or the lack thereof, is the key distinction between laws and conventions. $^{79}$ On the one hand, some legal rules are non-justiciable, or non-legally enforceable; on the other hand, some soft law rules are legally enforceable, and subject to

of the general election of 8 June.', 'The Referendum of 23 June 2017: Voting on Europe' [2017] PL (Brexit Special Issue) 1, at 8.

${ }^{73} \operatorname{Miller}$ (n 11) at [151].

${ }^{74} \mathrm{Eg}$, Jonathan Cape, (n 61); Evans, (n 62), Patriation Reference, (n 57). See generally, F Ahmed, R Albert, and A Perry, 'Judging Constitutional Conventions' (2017), available at: https://ssrn.com/abstract=3043190.

${ }^{75}$ Elliott (n 68), at 276; T Mullen, 'The Brexit Case and Constitutional Conventions' (2017) 21 Edinburgh Law Review 442, at 446.

${ }^{76}$ Ahmed et al, (n 74) at 30.

${ }^{77}$ Patriation Reference (n 55) at 880-881.

${ }^{78}$ Miller (n 11) at [145].

79 See generally J Jaconnelli, 'Do Constitutional Conventions Bind?' (2005) 64 CLJ 149; N Barber, The Constitutional State (Oxford University Press, 2010) at ch 10. 
interpretation by the courts. ${ }^{80}$ Moreover, some conventional rules operate to supplement rather than to modify legal rules, and therefore no issue of conflict with judges' duty to uphold the law arises.

Of course, that is not the case for all conventions, including the Sewel convention. Moreover, there might be greater concerns, given the political importance and sensitivity of some conventions (again including Sewel) about the appropriateness of judicial enforcement than there is in relation to other forms of soft law. However, here one might question the premise that judicial declaration of the meaning of a convention is tantamount to enforcement. As a general proposition, in other contexts the distinction between judicial declaration and judicial enforcement is regarded as constitutionally significant. The power of courts to issue declarations of incompatibility under section 4 of the Human Rights Act 1998, but not to invalidate legislation, is one example; the Crown's immunity from coercive remedies under section 21 of the Crown Proceedings Act 1948 is another. Moreover, the effect of any judicial ruling as to the meaning of a convention will depend both on how far the court is prepared to go in clarifying its meaning and upon the context in which the ruling is given. In Miller, for example, the Lord Advocate accepted that the meaning of the word 'normally' in the Sewel convention was non-justiciable, but argued that the Supreme Court could properly rule on the meaning of 'with regard to devolved matters'. ${ }^{81}$ Thus, even if the Court had held that the Convention did in principle apply to withdrawal legislation, it would still have been open to the UK Government to argue that this was a situation in which devolved consent could be dispensed with. Further, as already noted, given the essentially advisory nature of the Miller decision, and the fact that there was no actual Bill specifically under challenge, it is difficult to see how a declaratory ruling from the court would have involved questioning proceedings in Parliament.

Once again, the Supreme Court seems to have deliberately adopted a narrow view of its legitimate constitutional role, constructed around a sharp distinction between legal and political issues. At various points during the hearing and the judgment, the court was at pains to emphasise that its role in deciding the case was a purely legal rather than a political one:

It is ... worth emphasising that this case has nothing to do with issues such as the wisdom of the decision to withdraw from the European Union, the terms of withdrawal, the timetable or arrangements for withdrawal, or the details of any future relationship with the European Union. Those are all political issues which are matters for ministers and Parliament to resolve. They are not issues which are appropriate for resolution by judges, whose duty is to decide issues of law which are brought before them by individuals and entities exercising their rights of access to the courts in a democratic society. ${ }^{82}$ (emphasis added)

Thus:

The Sewel Convention has an important role in facilitating harmonious relationships between the UK Parliament and the devolved legislatures. But the policing of its scope and the manner of its operation does not lie within the constitutional remit of the judiciary, which is to protect the rule of law. ${ }^{83}$ (emphasis added)

\footnotetext{
${ }^{80}$ See A McHarg, 'Administrative Discretion, Administrative Rule-Making and Judicial Review' (2017) Current Legal Problems 267, at $279-281$, and at $284-285$.

${ }^{81}$ Oral transcript, day 3 (7 December 2016) 163, available at: https://www.supremecourt.uk/news/article-50brexit-appeal.html.

${ }_{82} \operatorname{Miller}(\mathrm{n} 11)$ at $[3]$.

${ }^{83}$ Ibid, at [151].
} 
This meant that the Supreme Court saw its role in resolving the dispute between the parties as a strictly limited one, encompassing only a subset of the constitutional issues at stake in the decision to withdraw from the EU. In this way, the Court may have considered that it was leaving open the maximum possible space for political deliberation and accommodation of the competing interests at stake, thereby reducing the risk of being accused of political interference. As regards the question of devolved consent, however, the effect of the court's refusal to rule on the application of the Sewel Convention was not neutral. Rather, it supported a reading of the territorial constitution which favoured the UK Government and Parliament over the devolved institutions; and it effectively closed off debate about the need for devolved consent rather than leaving it open for political resolution. This was not helped by the press summary of the judgment, which baldly stated that ' $[t]$ he devolved legislatures do not have a veto on the UK's decision to withdraw from the EU' ${ }^{84}$ Unsurprisingly, the decision was therefore reported as having rejected the devolved government's claims, rather than - more accurately — having refused to decide it, a spin happily encouraged by the UK Government which, indeed, made clear its displeasure to anyone who tried to suggest that the issue remained open. ${ }^{85}$ In this political context, the devolved governments ultimately chose to back down from a conflict that they were unlikely to win by not insisting on their right to consent to the EU (Notification of Withdrawal) Bill. ${ }^{86}$

\section{The Juridical Effect of Statutory 'Recognition' of the Sewel Convention}

The Supreme Court's concern to maintain its legitimacy by confining its decision to strictly legal questions was an understandable stance in the highly-charged political context of the Miller case. What is less understandable is why the statutory recognition of the Sewel convention by the Scotland Act 2016 was not regarded as providing sufficient legal cover to permit the court to rule on its meaning. According to the majority, the fact that Parliament was not seeking to give juridical effect to the convention:

follows from the nature of the content, and is acknowledged by the words ("it is recognised" and "will not normally"), of the relevant subsection. We would have expected UK Parliament to have used other words if it were seeking to convert a convention into a legal rule justiciable by the courts. ${ }^{87}$

\footnotetext{
${ }^{84}$ Available at: https://www.supremecourt.uk/cases/docs/uksc-2016-0196-press-summary.pdf.

85 See P Hutcheon, 'Advocate General for Scotland in Row with Law Society over Brexit', The Herald, 19 February 2017.

${ }^{86}$ The Scottish Government initially declared its intention to table a Legislative Consent Motion (LCM) before the Scottish Parliament, but ultimately did not, claiming that there was insufficient time to do so, given the accelerated timetable for consideration of the EU (Notification of Withdrawal) Bill at Westminster. Instead, a motion was debated in the Scottish Parliament on 7 February 2017 that 'the Parliament agrees ... that the UK Government's European Union (Notification of Withdrawal) Bill should not proceed', inter alia because 'the UK Government has set out no provision for effective consultation with the devolved administrations on reaching an agreed UK approach to the negotiations on implementing Article 50', which was passed by a majority of 90-34. Whether the timetable was the real reason for not pressing ahead with a formal LCM is not clear. It may be that the Scottish Government feared that an LCM would be rejected by the Presiding Officer, or decided that it would be preferable to avoid a direct confrontation with the UK Parliament (and thereby avoid setting a precedent for overriding a refusal of consent), or that a formal LCM would be less likely to gain cross-party support.

${ }^{87}$ Miller (n11) at [148].
} 
In response to the Lord Advocate's rhetorical question - 'what was the point in enshrining [the Convention] in law if it doesn't become a provision that the courts can address?' 88 — the Court argued that 'the purpose of the legislative recognition of the convention was to entrench it as a convention" ${ }^{\prime 89}$ (emphasis added).

If that was the purpose of section 28(8), then it is essentially a meaningless one. In the absence of an independent means of adjudication or enforcement, the convention is no more secure than it was previously. As Elliott puts it:

[i]f the Sewel Convention continues to be nothing more than a convention, then its normative source lies outside any legislation, and it remains a product of political consensus. If that consensus develops (or breaks down) then the convention will evolve (or disintegrate). ${ }^{90}$

In fact, the precise effect of statutory recognition was a matter of considerable controversy during the enactment of the Scotland Act 2016. ${ }^{91}$ The UK Government, certainly, was clear that it did not intend the convention to become justiciable. According to the Advocate-General for Scotland during the House of Lords Third Reading Debate:

we are not seeking, and nor are we able, to impose a restriction on Parliamentary sovereignty, ... This clause is clearly intended to indicate that the discretion of Parliament to legislate for devolved matters will continue exactly as before and that it is not intended to subject that discretion to judicial control. I would add that the words "it is recognised" ... also reflect the continued sovereignty of the UK Parliament and that it is for Parliament to determine when a circumstance may be considered not normal. This is not a matter that the courts could meaningfully engage with. ${ }^{92}$

Others were, however, less convinced. For instance, Lord Hope of Craighead objected that:

[w]ith all due respect to the Minister, he cannot get away with simply declaring that the "issue" is not justiciable ... there is a crucial difference between the position of Parliament legislating - and Ministers declaring what words mean when they legislate - and the position of the courts. The courts will assert their right to interpret the legislation according to the meaning of the words as they judge them to be ... the courts cannot close their door to arguments. ${ }^{93}$

Clearly, not every statutory provision is intended to create legal effects. ${ }^{94}$ Nevertheless, the usual starting point is a presumption that legislation is intended to change the law, ${ }^{95}$ which

\footnotetext{
${ }^{88}$ Oral transcript, day 3 (7 December 2016) at 166, available at: https://www.supremecourt.uk/news/article-50brexit-appeal.html.

${ }^{89} \operatorname{Miller}$ (n 11) at [150].

${ }^{90}$ Elliott (n 68) at 279.

${ }^{91}$ See: House of Commons Political and Constitutional Reform Committee, Constitutional Implications of the Government's Draft Scotland Clauses ( $9^{\text {th }}$ Report, 2014 - 15, HC 1022) at ch 2; House of Lords Constitution Committee, Scotland Bill (6 ${ }^{\text {th }}$ Report, $2015-16$, HL Paper 59) at paras 37-41.

92 HL Deb, Vol 769, cols 2070 - 2071 (21 March 2016).

${ }^{93}$ HL Deb, Vol 769, col 308 (24 February 2016). And see also Lord Hope, HL Deb Vol 769, col 207521 March 2016); Lord Lang of Monkton, HL Deb, Vol 767, cols 603 - 604 (24 November 2015) and HL Deb, Vol 769, col 281 (24 February 2016); Lord McCluskey, HL Deb, Vol 769, col 289 (24 February 2016) and HL Deb, Vol 769, cols 2071 - 2072 (21 March 2016).

${ }^{94}$ See D Feldman, 'Legislation Which Bears No Law' (2016) 37 Statute Law Review 212.

${ }^{95} \mathrm{Cf} R(S L) v$ Westminster City Council [2013] UKSC 27, per Lord Carnwath at [46]-[48]. See also K Campbell, 'The "Scotland Clauses" and Parliamentary Sovereignty' (2015) Juridical Review 259; C Crummey and E
} 
presumption needs to be convincingly rebutted. Arguably, the Supreme Court did not do enough to discharge this burden of proof. As regards the language of section 28(8), it is not self-evidently incapable of having legal effect. As the Lord Advocate argued with reference to other statutory contexts, the phrase 'it is recognised' 'doesn't point to any particular conclusion as to its juridical effect. ${ }^{96}$ Similarly, the inclusion of the word 'normally', while undoubtedly vague, does not necessarily render the provision incapable of legal effect - any more so than, for example, the use of the phrase 'necessary in a democratic society' in the European Convention on Human Rights.

As regards the content of section 28(8), the Supreme Court did not explain what it was about its content that suggested it was not intended to have legal effect, but presumably again it was the fact that it appears to limits Parliament's competence to legislate for Scotland. In other words, it seems to be in conflict with the principle of parliamentary sovereignty. This, however, is a problem of the enforceability of section 28(8), rather than its justiciability: it is not clear why it should also deprive the provision of the status of a legal rule. As judges have been willing to do in other contexts, the Supreme Court could have found a way to give the provision some meaningful legal effect, whilst also respecting Parliament's sovereign right to ignore it. For instance, both the Agnew appellants and the Counsel-General for Wales placed emphasis on the duty on UK Ministers to seek devolved consent in circumstances in which the Convention applies, rather than on the obligation of the UK Parliament to respect any refusal of consent.${ }^{97}$ Drawing an explicit analogy with the principle of legality, ${ }^{98}$ the Agnew appellants argued that:

if the Westminster Parliament wishes to legislate on EU withdrawal in the teeth of opposition from a devolved legislature (should that be the outcome of a request for an LCM [Legislative Consent Motion]), it should squarely confront what it is doing and accept the political cost. ${ }^{99}$

Moreover, the court could have resisted any suggestion of breaching Article 9 of the Bill of Rights ${ }^{100}$ by insisting — as the House of Lords did in the Jackson case — that ' $[\mathrm{t}]$ he proper interpretation of a statute is a matter for the courts, not Parliament. ${ }^{\prime 101}$

In a decision premised on the claim that the Supreme Court majority was merely upholding constitutional orthodoxy by defending Parliament's legislative supremacy against executive encroachment, it was perhaps impolitic to suggest that its sovereignty might in fact be constrained by a requirement of devolved consent. But the contrast between the majority's willingness to find meaning in the European Communities Act 1972 going well beyond the words actually used on the question whether the prerogative power to withdraw from the EU had been ousted by Parliament, while simultaneously denying legal effect to section 28(8) is

\footnotetext{
Velasco, 'Statutorily Entrenched Conventions: Conceptual Confusion or Sound Constitutional Development', paper presented at ICON-S British and Irish Chapter Inaugural Conference, Trinity College Dublin, September 2017 (paper on file with the author).

${ }^{96}$ Oral transcript, day 4 (8 December 2016) at 9-10, available at: https://www.supremecourt.uk/news/article-50brexit-appeal.html.

${ }^{97}$ Agnew (n 15), [127]-[129]; Counsel General, (n 15) at paras 82-83.

${ }^{98} R v$ Secretary of State for the Home Department, ex parte Simms [2000] 2 AC 115, per Lord Hoffman at [131].

${ }^{99}$ Agnew (n 15), [141].

${ }^{100}$ See, e.g., Grant, (n 69) at 58.

${ }^{101} R$ (Jackson) v Attorney General [2006] 1 AC 262 at [51].
} 
striking. ${ }^{102}$ The retreat from creativity into formalism in relation to the devolution issues ${ }^{103}$ suggests that the Court simply did not regard them as important — or at least not sufficiently important to risk compromising its fragile legitimacy. ${ }^{104}$

\section{THE IMPLICATIONS OF MILLER FOR THE TERRITORIAL CONSTITUTION}

Although they were unsuccessful in their claim that devolved consent was required to begin the process of withdrawing from the EU, it is too simplistic to present Miller as a straightforward loss for the devolved governments. They were, after all, no worse off than if the UK Government had maintained its position that Article 50 could lawfully be triggered under the prerogative. Moreover, given the novelty of the constitutional claim that the devolved parties were advancing, there was no guarantee, even if the Supreme Court had been willing to rule on the meaning of the Sewel convention, that it would have found that devolved consent was required. At the very least, the Court's refusal to intervene avoided the risk of another unhelpfully narrow statement of the convention of the kind made by the HCNI in McCord. Thus, if the devolved governments failed in their offensive campaign, they at least succeeded in their defensive one: preserving their position on the need for devolved consent to the domestic implications of Brexit. Accordingly, as noted earlier, the UK Government has not sought to dispute that Sewel does apply to the EU (Withdrawal) Bill, even where this engages the constitutional rather than the policy arm of the Convention (and notwithstanding that, as currently drafted, the change to devolved competences is largely one of form rather than substance). This has given the devolved governments a means by which to force the UK Government - albeit belatedly - to negotiate over the terms of the legislation. ${ }^{105}$

However, the Miller decision has undoubtedly done some damage to territorial relations within the UK. In the first place, in refusing to give legal effect to the statutory recognition of the Sewel convention the Supreme Court has undermined a central element of the postindependence referendum attempt to strengthen the devolution settlement in Scotland (and subsequently also in Wales). Although the provisions may still have some legal relevance in supporting a presumption that Parliament does not intend to legislate in regard to devolved matters without consent, ${ }^{106}$ and although they may never have been intended to provide more than symbolic reassurance, for the Supreme Court to have so casually dismissed them simply confirms a key anxiety in the UK's minority nations about their lack of constitutional security, which cannot be resolved without root and branch constitutional reform, if at all. ${ }^{107}$

Secondly, the decision may also have done some damage to the Sewel convention as a convention. Page claims that the convention 'remains no less politically binding than before', ${ }^{108}$

\footnotetext{
102 Cf K Ewing, 'Brexit and Parliamentary Sovereignty' (2017) 80 MLR 711,722 - 723.

${ }^{103}$ P Daly, 'Miller: Legal and Political Faultlines' [2017] PL (Brexit Special Issue) 73.

104 Cf JEK Murkens, 'Mixed Messages in Bottles: the European Union, Devolution, and the Future of the Constitution' (2017) 80 MLR 685, at 686, 690-691; C McCrudden and D. Halberstam, 'Northern Ireland's Supreme Court Brexit Problem (and the UK's too)', UK Const L Blog (21 November 2017).

105 See Joint Ministerial Committee (European Negotiations) Communiqué, 16 October 2017, available at: https://www.gov.uk/government/uploads/system/uploads/attachment_data/file/652285/Joint_Ministerial_Comm ittee_communique.pdf.

106 See R Ekins, 'Legislative Freedom in the United Kingdom' (2017) 133 LQR 582, at 583.

${ }^{107}$ See A McHarg, 'The Future of the United Kingdom's Territorial Constitution: Can the Union Survive?' (2016), available at: https://papers.ssrn.com/sol3/papers.cfm?abstract id=2771614.

${ }^{108}$ A Page, 'Brexit, the Repatriation of Competences and the Future of the Union' (2017) Juridical Review 39, at 41.
} 
but Miller has arguably weakened it in several different ways. The ability of conventions to constrain constitutional behaviour depends upon a combination of two factors: the sense of obligation felt by those actors subject to the convention to follow it; and the likelihood of political sanctions if the convention is breached. As regards the sense of obligation, although the Supreme Court was careful to emphasise the importance of constitutional conventions notwithstanding their lack of legal enforceability, the contrast in the decision between strong protection for legal rules and the absence of equivalent protection for conventional rules does tend to undermine the significance of the latter. ${ }^{109}$ More specifically, the hardening of political attitudes engendered by the litigation may well have made it less likely that the UK Government would accept the expansive claim to constitutional power-sharing being made in the name of the Sewel Convention. Thus, despite initially committing to the 'full engagement' of the devolved governments in establishing the UK's negotiating position on Brexit, ${ }^{110}$ this commitment waned over time in favour of a reassertion of the decisiveness of the UK-wide Brexit vote and of the UK Government's right to determine its meaning.

The Miller decision may also have contributed to a weakening of the political risks associated with ignoring the Sewel convention, at least as regards Scotland. Having been denied a voice in the decision to leave the EU, Scotland's First Minister Nicola Sturgeon invoked the option that had been 'on the table' since the EU referendum of Scotland's exit from the Union. Two weeks before the Prime Minister formally triggered Article 50, Sturgeon acted — precipitously as it turned out — on her threat to call a second independence referendum. With this threat apparently neutralised by the result of the unexpected general election of 8 June 2017, in which the SNP lost both seats and votes following a campaign in which opposition to a second independence referendum had been a key issue in Scotland, the UK Government's unitarist approach to Brexit seems to have been further emboldened. Thus, when the EU (Withdrawal) Bill was published in July 2017, far from enhancing the powers of the devolved legislatures, it allocated all policy competences returning from the EU to the UK Parliament, leaving it to UK ministers unilaterally to decide if and when powers were to be devolved. At the time of writing it is unclear whether agreement will be reached on a different approach, or what will happen if it is not.

The third problem is the damage that Miller may have done to the perception of the Supreme Court as a neutral arbiter in future disputes in which the status of devolution, or the conflicting authority of UK and devolved institutions, is at stake. Certainly, it may be argued that such disputes are best kept out of the courts anyway. In Miller, the constitutional merits of requiring devolved consent were far from clear cut, and could have produced significant anomalies given the variations in constitutional practice and statutory recognition as between the various devolved territories. If the litigation had never occurred, a more satisfactory political solution might have been found. But successful reliance on convention and political agreement requires a high degree of constitutional trust; where such trust is weak or absent, actors will naturally look for an independent referee. Miller is symptomatic of the stronger expectation in recent years that UK courts will become involved in resolving high profile constitutional disputes, and of judges' greater willingness to do so. But it also illustrates the difficulties of negotiating the judicial role in a complex constitutional order which is (still) only

${ }^{109}$ Cf Lord Wilson of Dinton, 'The Robustness of Conventions in a Time of Modernisation and Change' [2004] PL 407; House of Commons Political and Constitutional Reform Committee, A New Magna Carta (2 $2^{\text {nd }}$ Report 2014 - 15, HC 463), at 385-386.

110 See David Cameron's resignation speech on 24 July 2016, available at: http://www.telegraph.co.uk/news/2016/06/24/david-cameron-announces-his-resignation---full-statement/. 
partially regulated by law. In choosing to cast themselves as defenders of the Rule of Law, rather than as guardians of the constitution, there is a danger that that role becomes a partial one in both senses of the word. 